Rupantaran : A Multidisciplinary Journal

Vol. IV : pp 11-19, October, 2020

ISSN : 2091-0061

https://doi.org/10.3126/rupantaran.v4i1.34013

Research Management Cell (RMC)

Dhankuta Multiple Campus, Dhankuta

Tribhuvan University, Nepal

\title{
Relation between Insurance and Economic Growth in Nepal
}

\author{
Arjun Bikram Khadka ${ }^{1}$ \\ Email:khadkaarjunbikram@gmail.com
}

\section{Abstract}

This paper scrutinizes the relationship between insurance penetration and economic growth of Nepal on annual macroeconomic data for the period of 1997-2017 source from World Bank's database. This paper has revealed the behavior of Nepalese insurance on the context of economic growth. Pragmatic results show positively high correlation between penetration and economic growth. However, there is very low percentage of insured population in Nepal. Descriptive statistics and Pearson correlation was used to diagnose results from data collected from world bank database. This study discloses the positive and significant relationship between insurance penetration and economic growth.

Key Words: economic growth, insurance penetration, insurance market, macroeconomic data

\section{Introduction}

Financial sectors of a country are considered as a vital part of its economic growth. An effective and well-developed financial system helps to increase productivity and subsequently the economic growth. Insurance is an important part in the financial sector that contributes significantly to the economy of a country. Insurance market contributes to the economic growth as a financial intermediary and also helps in managing risk more effectively (Ward \& Zurburegg, 2000). Moreover, insurance contributes to the promotion of financial stability, facilitation of trade and commerce, management of risk in an effective manner, mobilization of savings, allocation of capital in an effective way and also it acts as a complement of Government security programs (Webb, Grace \& Skipper, 2002).

1. Mr. Khadka is Lecturer of Economics at Mahendra Morang Adarsha Multiple Campus, Biratnagar, TU, Nepal. 
The importance of the insurance-growth nexus is growing due to the increasing share of the insurance sector in the aggregate financial sector in almost every emerging and mature market economy. Literature dealing with the interaction between the financial sector and economic growth is merely concerned with bank and stock markets. The role of the financial sector for economic growth has become a major topic of empirical research in the last decade or so, greatly elaborating on the research works.

Outreville (1996) successively used the property rights data of 55 developing countries and the life insurance data of 48 developing countries to reveal the natural close relationship between insurance industry and economic growth: elasticity of per capita insurance expenditure versus per capita GDP is greater than 1, per capita insurance demand is function of per capita GDP, financial development level and premium. Skipper (2001) argues that insurance contributes to economic growth in six areas: enhancing financial stability, facilitating business and trade, mobilizing domestic savings, effectively controlling risk, promoting effective allocation of capital and reducing losses. Not only that, insurance can invigorate market transactions and maintain financial stability through risk identification and risk transfer (Ward \& Zurburegg, 2000), and even replace and supplement government support programs (Skipper, 2001). To some extent, stimulus effect of insurance on economic growth is seen as an endogenous function (Regan \& Hur, 2007) which promotes economic growth by means of risk transmission, asset allocation and influence in economic unit decision making (Das, 2003). For developing countries, the positive role of insurance in infrastructure construction, foreign direct investment and job creation cannot be ignored (Rao \& Srinivasu, 2013).

Insurance can be broadly categorized as life insurance, non-life insurance and reinsurance. Life insurance represents the long- term funds whereas the non-life insurance represents short -term funds. Reinsurance can be defined as security of other insurance company against loss. However, existing literatures show that insurance development significantly affect the economic growth.

Previously many scholars have suggested the relationship between insurance and economic growth revealing that the degree of insurance development is influenced by the level of economic development of the country. An insurance company has different product for different country because of requirement of particular environment. Barker (2019) states that countries with large uninsured population have different need in regard to insurance where are countries with less uninsured population have different requirement of insurance. The basic benefit of insurance is risk coverage but there are certain counties that deem for risk as well as monetary return. Addition to it, 
the degree of insurance development is simultaneously influenced by religion (Gill, Mand, Biger \& Mathur, 2018) culture (Park \& Lemaire, 2012) and education (Maria, Cristina, Ioncica, \& Constantinescu, 2012).

Especially in modern period insurance succeed in economy. In developed countries such as Germany, England, Switzerland, France insurance became vital part of the economy. In these countries people trust insurance, and for this reason they insure all assets in famous insurance companies. On the other hand, insurance lets people and also businesses to protect themselves against certain potential losses and financial hardship at a reasonable acceptable rate. In modern period there are some insurance types which play great role in economy. For example, people use motor insurance, property insurance, medical insurance, life insurance widely. These insurance types have great importance also in social life. Because when people use insurance types, it effects positively to their life style, social activity and also longevity.

Insurance has become a vital component for economic development not just in developed but even in developing countries. In developed countries like America $2.9 \%$ of GDP is contributed by insurance (Insurance information institute, 2019). In developed countries insurance is a part of education, tradition, life style, while in Nepal, we are far from educating and discussing about insurance to any part of the population. The basic purpose of this study is to examine the relationship between insurance and economic growth in Nepalese context. Does the insurance have any influence on economic development or there is no any effect of insurance with economic development?

\section{Literature Review}

The growth of financial institution and influence of it in economic growth has been well recognized and many researches have been conducted on this topic. Jung (1986) worked on this topic for the first time and Rousseau \& Wachtel (1998); Levine, Loayza \& Beck (2000) and others provide evidence on the relationship between financial development and economic growth. Hussels et al., (2005) states that previous study only focused on the determination of factors that influence of demand of insurance and economic development. But there are number of studies that studies the relationship between insurance and economic growth.

The association between insurance and economic growth has been researched by number of scholars and depicted direct and causal link. The development of insurance and reinsurance is essential for economic development of any country as it reduces uncertainty and encourages long-term investment (Feyen, Lester \& Rocha, 2011). An Empirical Investigation with the help of simultaneous equation, empirically 
investigates the interaction between financial development and economic growth which reveals that there is a significant and positive relationship between economic growth and financial intermediary.

A study conducted by showed a positive relationship between insurance and economic growth in Nepal. Moreover, researcher reveals there is a larger population who are uninsured (Pant, \& KC (2018). Haiss \& Sümegi (2008) contend that the insurance sector is important to economic growth as it can be used as a channel of risk transfer, saving and investment. In their study of 29 European countries they found out that the aggregate investment by insurance companies grew by $20 \%$ relative to gross domestic product (GDP) within the time span of 1993-2004. They go on to observe that an essential part of the contribution of insurance companies to GDP growth derives from their assets, their investment activities and the companies' setup. Thus, the participation by insurance companies in the economy results in the expansion of the investment horizon, increase of market volume and improvement of market efficiency.

A cross country panel study of 29 European countries conducted by Haiss \& Sümegi (2008) reveals that there is a positive impact of insurance on GDP growth. They even added that interest rate and economic development were the prime factor for insurance growth. Ul Din, Regupathi \& Abu Bakar (2017) studied that there is positive and significant relationship between life insurance, measured through net written premiums and density and economic growth for developed countries while the same is true for developing countries when insurance is measured through penetration proxy. They formulated a proxy data for developing countries and found the same relationship between insurance and economic growth.

Webb, Grace \& Skipper (2002) tried to examine whether banks, life and non-life insurance individually and collectively contribute to economic growth, to do this they used data from 55 countries for the period 1980-1996. The result of this research is that the penetration of life insurance is significantly positively correlated with economic growth and the relationship is reciprocal. In addition, they stated that there is no link between economic development and non-life insurance.

Valentina, Kęstutis, Gitana \& Kęstutis (2019) stated that a positive statistically significant relationship between insurance penetration and economic growth has been detected in Luxembourg, Denmark, The Netherlands and Finland and a negative statistically significant relationship has been identified in Austria, Belgium, Malta, Estonia and Slovakia. This study suggests that even though the country is developed there is no confirm theory that insurance development has direct impact in country's economic development. Similarly, a study conducted by Lee (2019) showed causal 
relationship between insurance and economic growth. The study reveals indirect relationship and states the investment capacity of insurers determines the performance of insurance development. This paper studies the relationship between insurance growth and economic development in Nepal because few studies have only been conducted in this area. The main purpose of this paper is to find out the size of insurance market in Nepal. This paper has taken Insurance Penetration as the indicator of Insurance growth. In order to revel the correlation between insurance and economic growth in Nepal, we have tested several statistical methods in the analysis.

\section{Insurance Market of Emerging Asian countries}

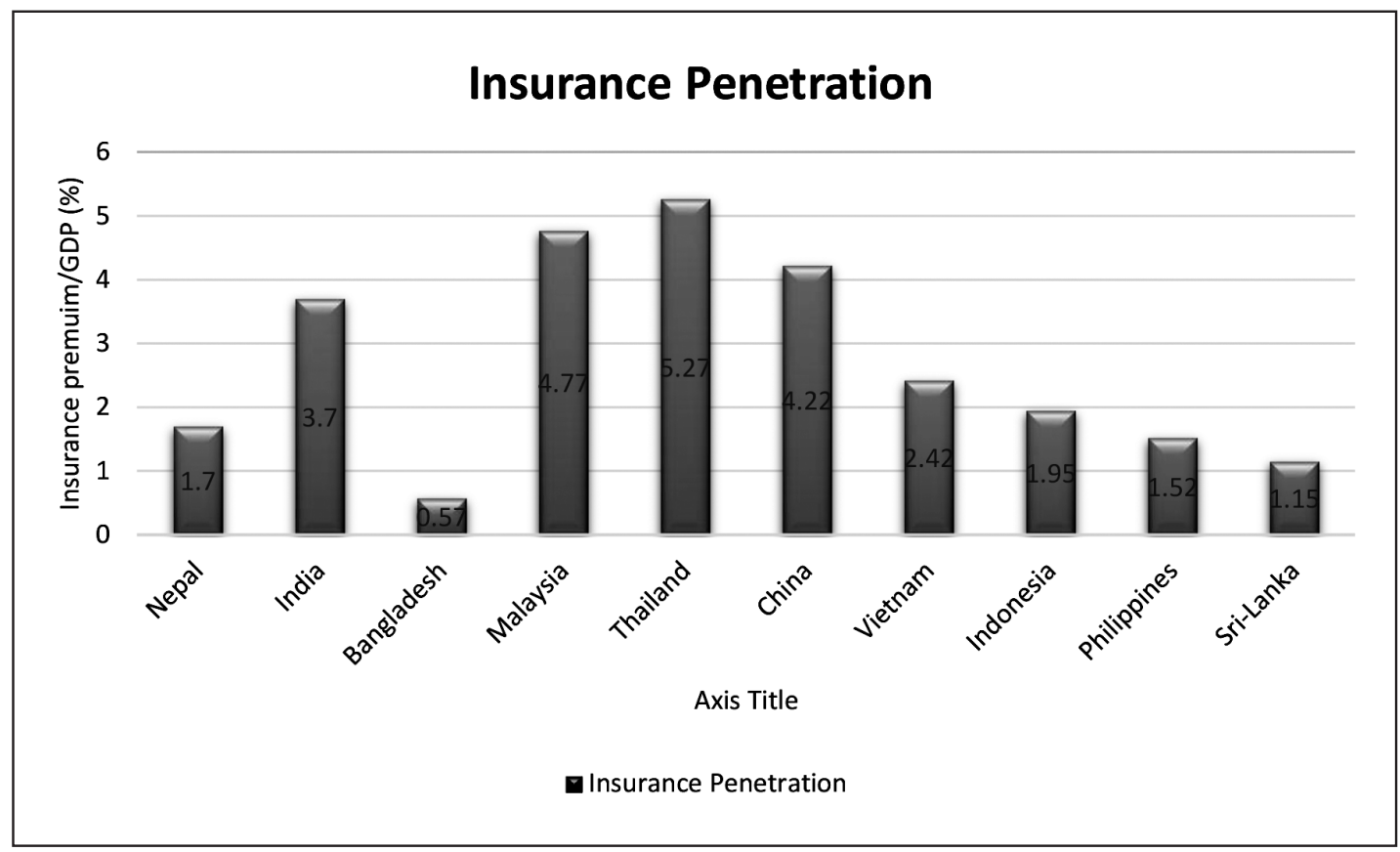

Source: World Bank

Amongst the emerging Asian countries, the graph shows Thailand (5.27\%) as the Asian country that has highest insurance penetration. Insurance has contributed $5.27 \%$ out of the total GDP followed by Malaysia (4.77\%), China (4.22\%), India (3.7\%), Vietnam (2.42\%) and Indonesia (1.95\%). The country that has least insurance contribution to GDP is Bangladesh (0.57\%) followed by Sri-Lanka (1.15\%), Nepal (1.7\%) and Philippines (1.52\%).

The bar graph shows that insurance has greater contribution in Thailand's economy with $5.27 \%$ and least in Bangladesh with $0.57 \%$. As Thailand is home to many insurance companies it has witness huge contribution of insurance whereas there no long history of insurance in Bangladesh. 
Insurance Penetration in Nepal (1997-2017)

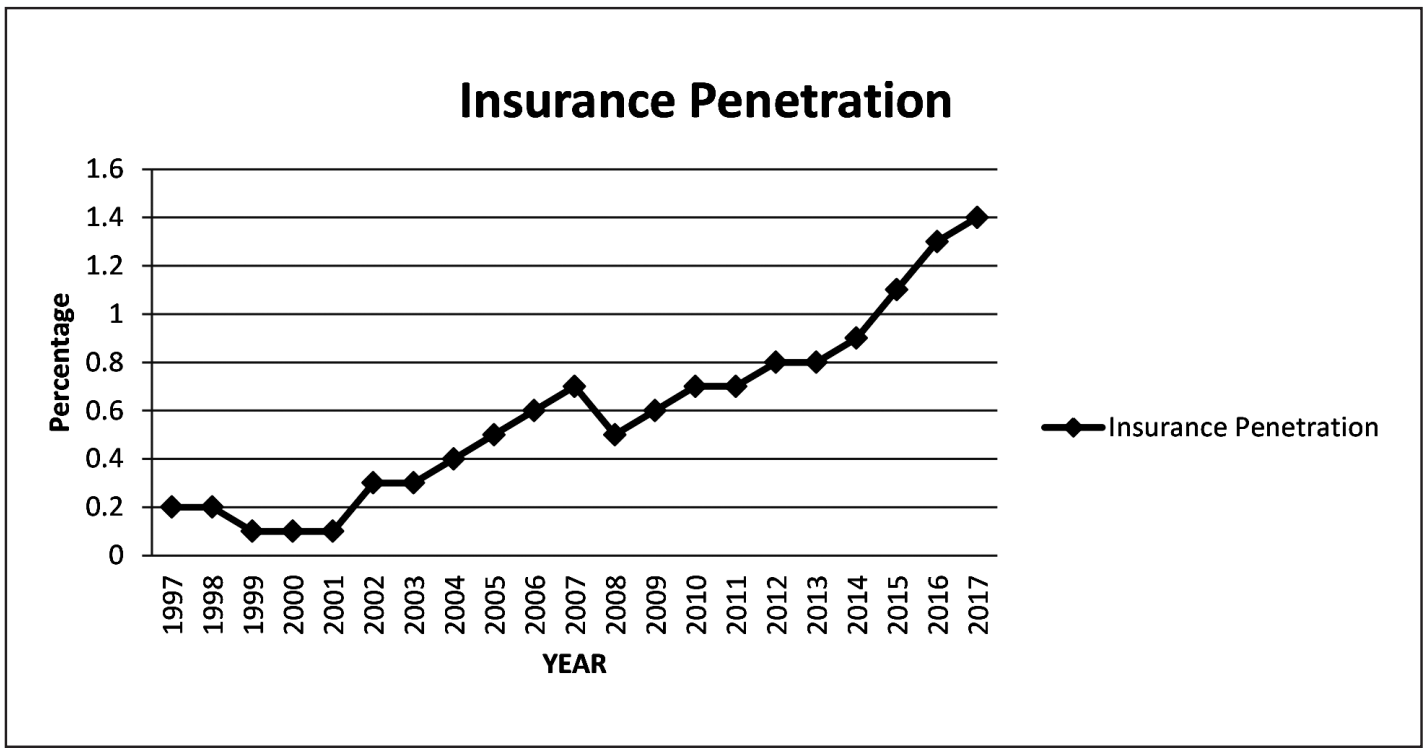

Source: World Bank

The given line graph shows the insurance penetration of Nepal from 119 to 2017 AD. Insurance penetration is the amount is the life insurance premium volume to GDP in percent. The data presented has been obtained from World Bank database. The line shows increasing trend of insurance penetration in Nepal. The highest penetration is in the year 2017 at 1.4\% of entire GDP of Nepal. Year 1999, 2000 and 2001 have faced the lowest insurance penetration at $0.1 \%$. Ten new entrants in life insurance in 2017 with total 19 companies operating in Nepal has given rise to penetration of Life insurance in Nepal. A gradual increment picture can be seen from the year 2003 to 2017. We can assume that the insurance has accelerate in pace and getting momentum in Nepal.

\section{Results and Discussion}

This research is longitudinal and based in time series data. This study has employed Nepal's data from 1997 to 2017. This period has been chosen because of gradual increment in life insurance penetration in Nepal. The data are analyzed and presented using SPSS.

Table 1: Descriptive statistics of Variables

\begin{tabular}{llllll}
\hline Variables & N & Minimum & Maximum & Mean & Std. Deviation \\
\hline Income (GDP) & 21 & 4.856 & 25.181 & 12.36586 & 6.771185 \\
Penetration & 21 & 0.1 & 1.4 & 0.586 & 0.3798 \\
\hline
\end{tabular}


Table 1 shows the average mean of GDP and insurance penetration for the period of 1997-2017. The table depicts that the GDP average mean is 12.36586 and insurance penetration is $0.586 \%$. On an average we can find that the insurance hasn't been a popular contributor to Nepalese economy growth. To check the relationship between insurance penetration and economic growth, we need to use Pearson Correlation Analysis.

\section{Pearson Correlation Analysis}

Table 2: Pearson Correlation Analysis

\begin{tabular}{llll}
\hline Variable & & Income & Penetration \\
\hline Income & Pearson Correlation & 1 & $.936^{* *}$ \\
& Sig. (2-tailed) & & 0.000 \\
& $\mathrm{~N}$ & 21 & 21 \\
Penetration & Pearson Correlation & $.936^{* *}$ & 1 \\
& Sig. (2-tailed) & 0.000 & \\
& $\mathrm{~N}$ & 21 & 21 \\
\hline
\end{tabular}

Table 2 shows the correlation between insurance penetration and economic growth (GDP) of Nepal from the period of 1997-2017. Penetration and economic growth have a positive and significant relationship. A 0.936 degree is correlation is significant. The result indicates that penetration and economic growth have positively high correlation between them. A p-value of 0.000 which is less than 0.005 indicates a significant relationship between them. There is no case of Multicollinearity as VIF is not more than 10 .

\section{Conclusion}

The intention of this paper is to offer a methodical calculation based on statistical methods and a panel data gathered along 21 years and relationship between insurance penetration and economic growth of Nepal. There are numbers of research conducted in Nepal in relation between various soci0-economic variables and insurance demand but few researches have conducted in this field. The result has established a high correlation between penetration and economic growth. Correspondingly, the results of other developed countries, the relationship between penetration and economic growth is Nepal is same. But, the total insured population of Nepal is only $18 \%$ which gives a potential opportunity to the insurance companies. The government as well as the policy maker should give optimal focus on how to insure the remaining $82 \%$ population. Nepal is the country where citizens have lack of insurance need to be made aware of its importance. Of all the policies issued more than $90 \%$ are all because 
of agent based sales. It has been overlooked and treated as an Unsought product. The result shows a high correlation between penetration and economic growth, we can state that if we develop the insurance sector parallelly the economic standard of the country will flourish. Like in various Asian countries, Insurance can be an important contributor in economic growth of Nepal, so insurance companies along with the support of government need to make people aware about the benefits and value of life insurance.

\section{References}

Barker, A. (2019). Effect of Population Size on Rural Health Insurance Premiums in the Federal Employees Health Benefits Program. Health Affairs. 38. 2041-2047. 10.1377/hlthaff.2019.00912.

Das, D. (2003) Insurance and Issues in Financial Soundness. IMF Working Paper. 5(21):3-40

Feyen, E., Lester, R., \& Rocha, R. (2011). What Drives the Development of the Insurance Sector? An Empirical Analysis Based on a Panel of Developed and Developing Countries. Policy Research Working Paper. 1-43.

Gill, A., Mand, H., Biger, N \& Mathur, N. (2018). Influence of religious beliefs and spirituality on decision to insure. International Journal of Emerging Markets. 13. 00-00. 10.1108/IJoEM-07-2017-0235.

Haiss, P \& Sümegi, K. (2008). The Relationship Between Insurance and Economic Growth in Europe: A Theoretical and Empirical Analysis. Empirica. 35. 405431. 10.1007/s10663-008-9075-2.

Hussels, S., Ward, D \& Zurbruegg, R. (2005). Stimulating the demand for insurance. Risk Management and Insurance Review. Vol. 8 No. 2, pp. 257-78.

Jung, W. S. (1986). Financial Development and Economic Growth: International Evidence. Economic Development and Cultural Change. 34(2): 333-346.

Lee, H. (2019). Insurance Development and Economic Growth. Financial Statistical Journal. 1. 10.24294/fsj.v1i4.1057.

Levine, R., Loayza. N, \& Beck, T. (2000) . Financial Intermediation and Growth: Causality and Causes. Journal of Monetary Economics. 46(1): 31-77

Maria, I., Eva-Cristina, P., Ioncica, D \& Constantinescu, M. (2012). The Role of Education on Consumer Behavior on the Insurance Market. Procedia - Social and Behavioral Sciences. 46. 4154-4158. 10.1016/j.sbspro.2012.06.217.

Outreville, J. (1996). Life Insurance Markets in Developing Countries. The Journal of Risk and Insurance. 63(2), 263-278. doi:10.2307/253745

Pant, S \& KC, F. (2018). Contribution of Insurance in Economic Growth of Nepal. Journal of Advanced Academic Research. 4. 99. 10.3126/jaar.v4i1.19523. 
Park, S \& Lemaire, J. (2012). The Impact of Culture on the Demand for Non-Life Insurance. ASTIN Bulletin. 42. 10.2143/AST.42.2.2182806.

Rao, M \& Srinivasulu, R. (2013) Contribution of Insurance Sector to Growth and Development of the India Economy. Journal of Business and Management. $7(4): 45-52$

Regan, L. \& Y. Hur. (2007). On the Corporate Demand for Insurance: The Case of Korean Non-Financial Firms. Journal of Risk and Insurance. 74(4):829-850

Rousseau, P. L \& Wachtel, P. (1998). Financial Intermediation and Economic Performance: Historical Evidence From Five Industrialized Countries. Journal of Money, Credit and Banking. 30(4): 658-678.

Skipper, H. D. (2001). Insurance in the general agreement on trade in services America. Enterprise Institute.

U1 Din., S, M., Regupathi, A \& Abu Bakar, A. (2017). Does Insurance Promotes Economic Growth:AComparative Study of Developed andEmerging/Developing Economies. Cogent Economics \& Finance. 5. 10.1080/23322039.2017.1390029. Valentina, P., Kęstutis, P., Gitana, D \& Kęstutis, K. P (2019). The relationship between insurance and economic growth: evidence from the European Union countries. Economic Research-Ekonomska Istraživanja. 32:1, 1138-1151, DOI: 10.1080/1331677X.2019.1588765

Ward, D \& Zurburegg, R. (2000). Does Insurance Promote Economic Growth? Evidence from OECD Countries. Journal of Risk and Insurance. Vol. 67, No. 4, pp.489-506.

Webb, I. P., Grace, M. F., Skipper, H. D. (2002). The Effect of Banking and Insurance on the Growth of Capital and Output. Center for Risk Management and Insurance Working Paper. 02-1. http://rmictr.gsu.edu/working.htm. Cited March 15, 2007 https://www.iii.org/publications/a-firm-foundation-how-insurance-supportsthe-economy/introduction/insurance-industry-at-a-glance. 